\title{
PENGARUH SISTEM OLAH TANAH TERHADAP PERTUMBUHAN, SERAPAN HARA DAN PRODUKSI TANAMAN JAGUNG PADA TANAH ULTISOL GEDUNG MENENG BANDAR LAMPUNG
}

\author{
Harris Oktaviansyah, Jamalam Lumbanraja, Sunyoto \& Sarno \\ Jurusan Agroteknologi Fakultas Pertanian Universitas Lampung \\ J1. Prof. Soemantri Brodjonegoro, No. 1 Bandar Lampung 35145 \\ E-mail: harrisoktaviansyah1991@gmail.com
}

\begin{abstract}
ABSTRAK
Teknik persiapan lahan pada percobaan ini dikelompokkan ke dalam sistem olah tanah sempurna (OTS) dan olah tanah minimum (OTM). Olah tanah sempurna yang umumnya menggunakan alat-alat sederhana hingga alat-alat berat pada dasarnya bertujuan mengendalikan gulma dan menggemburkan tanah sehingga aerasi dan kapasitas infiltrasi tanah meningkat. Penelitian ini bertujuan untuk mempelajari pengaruh olah tanah dan herbisida terhadap pertumbuhan, serapan hara dan produksi tanaman jagung serta nilai ekonomisnya. Penelitian ini dilaksanakan di Laboratorium Lapang Terpadu dan Laboratorium Ilmu Tanah Universitas Lampung pada bulan Februari 2014 hingga Mei 2014. Plot percobaan disusun dalamRancangan Acak Kelompok (RAK) yang terdiri dari 4 perlakuan yaitu $\mathrm{A}$ (olah tanah minimum), B (olah tanah minimum+herbisida), $\mathrm{C}$ (olah tanah sempurna), $\mathrm{D}$ (olah tanah sempurna therbisida) dengan 4 ulangan. Hasil penelitian menunjukan bahwa perlakuan olah tanah minimum + herbisida secara nyata lebih tinggi menghasilkan bobot pipilan basah, bobot pipilan kering oven, bobot pipilan KA 14\%, dan bobot kering total tanaman dibandingkan dibandingkan perlakuan lainnya. Olah tanah minimum + herbisida secara nyata lebih tinggi menghasilkan serapan hara total tanaman N, P, dan K dibandingkan olah tanah minimum, olah tanah sempurna, dan olah tanah sempurna + herbisida. Serapan hara N P K berkorelasi positif terhadap jumlah daun, bobot pipilan, bobot bonggol, dan bobot brangkasan tanaman jagung. Dalam hal R (nisbah penerimaan terhadap pengeluaran), olah tanah minimum + herbisida menghasilkan nilai ekonomis tertinggi dibandingkan olah tanah minimum, olah tanah sempurna, dan olah tanah sempurna + herbisida.
\end{abstract}

Kata kunci : olah tanah minimum, olah tanah sempurna

\section{PENDAHULUAN}

Jagung merupakan bahan pangan pokok kedua setelah beras yang memiliki banyak manfaat dan dapat diolah menjadi berbagai jenis bahan makanan, bahan pakan ternak dan bahan baku industri.Menurut BPS (2014), total produksi jagung di Indonesia pada tahun 2013 mencapai 18.511.853ton dengan luas lahan 3.821.504ha setara dengan $4,84 \mathrm{t} \mathrm{ha}^{-1}$, sedangkan total produksi jagung di Provinsi Lampung pada tahun 2013 mencapai 1.760.278ton dengan luas panen sebesar 346.315hasetara dengan 5,08 $\mathrm{tha}^{-1}$.

Kebutuhan jagung akan terus meningkat sejalan dengan pertambahan jumlah penduduk dan terus berkembangnya industri pakan serta industri berbahan baku jagung, oleh karena itu produksi tanaman jagung harus terus ditingkatkan. Salah satu upaya dalam meningkatkan produksi jagung juga dapat dilakukan dengan meningkatkan produktivitas lahan. Produktivitas lahan dipengaruhi oleh jenis tanah, jenis tanaman, sarana produksi dan teknologi budidaya.
Jenis tanah yang ada di Provinsi Lampung didominasi Tanah Ultisol. Tanah Ultisol merupakan jenis tanah dengan kandungan liat yang tinggi, sehingga ketika kekeringan permukaan Tanah Ultisol banyak terdapat retakan sedangkan ketika kandungan air nya tinggi tanahnya akan lengket dan air terus menggenang. Pengolahan tanah merupakan bagian dari upaya untuk meningkatkan produktivitas lahan khususnya untuk Tanah Ultisol.

Pengolahan tanah terdiri dari olah tanah konservasi dan olah tanah intensif. Pada sistem olah tanah kenservasi, tanah diolah seperlunya saja disekitar lubang tanam dan pengendalian gulma dilakukan dengan cara manual (dibesik); gulma yang mati dapat dijadikan bahan organik tanah. Apabila cara manual kurang efektif, pengendalian gulma dapat dilakukan dengan aplikasi herbisida. Sedangkan pengolahan tanah intensifadalah pencangkulan sedalam $15-20 \mathrm{~cm}$. Hal ini dapat memberikan lingkungan tumbuh yang baik bagi tanaman, yaitu struktur tanah menjadi remah dan dapat mengendalikan pertumbuhan gulma sehingga diperoleh 
hasil yang tinggi tetapihal ini dapat menyebabkan tanah lebih terbuka dan mudah tererosi,sehingga meningkatkan degredasi lingkungan dan menurunkan produktivitas tanah (Utomo, 1995).

Berdasarkan hasil penelitian yang dilakukan Syaputra (2012) menunjukan bahwa produksi jagung tertinggi terdapat pada sistem olah tanah minimum yaitu $5,89 \mathrm{t} \mathrm{ha}^{-1}$, sedangkan produksi jagung terendah pada sistem olah tanah intensif sebesar $4,38 \mathrm{t} \mathrm{ha}^{-1}$. Peningkatan produksi tanaman pada olah tanah minimun dibandingkan olah tanah intensif disebabkan oleh beberapa faktor diantaranya meningkatnya ketersediaan air tanah dan dapat ditekannya kehilangan hara karena erosi.

Namun demikian terdapat beberapa hasil penelitian yang menunjukkan bahwa olah tanah sempurna (OTS) mampu menghasilkan produksi tanaman jagung lebih tinggi dibandingkan olah tanah minimum(OTM). Hal tersebut dibuktikan pada penelitian Azwir (2012) OTS menghasilkan produksi jagung 7,22 $\mathrm{t} \mathrm{ha}^{-1}$, sedangkan pada OTM sebesar 6,96 $\mathrm{t} \mathrm{ha}^{-1}$.

Efisiensi dalam pengolahan tanah dapat dilihat dari waktu,tenaga, dan biaya yang diperlukan. Olah tanah minimum dapat menghemat waktu dalam persiapan lahan, menguraingi jumlah tenaga kerja yang diperlukan, dan pada akhirnya biaya yang dikeluarkan dapat ditekan sehingga meningkatkan pendapatan petani. Sedangkan pengolahan intensif atau sempurna dengan mencangkul danmebajak sampai gembur dan bersih tidak hanya berakibat buruk terhadap peningkatandegradasi tanah tetapi juga memerlukan banyak tenaga kerja dan biaya dalam proses persipanlahan tanam (Azwir, 2012).

Dari beberapa penjelasan diatas, maka penelitian ini dilakukan untuk mempelajari pengaruh sistem olah tanah terhadap pertumbuhan, serapan hara, dan produksi tanaman jagung serta nilai ekonomisnya. Tujuan penelitian ini adalah mempelajari pengaruh sistem olah tanah dan herbisida terhadap pertumbuhan, serapan hara, dan produksi tanaman jagung serta mempelajari efisiensi pengolahan tanah dan herbisida terhadap produksi,tanaman jagung.

\section{BAHAN DAN METODE}

Penelitian ini dilakukan di Laboratorium Lapang Terpadu Universitas Lampung dari bulan Februari 2014 sampai dengan Mei 2014 pada 5'22'10"LS dan $105^{\circ} 14^{\prime} 38^{\prime \prime} \mathrm{BT}$ dengan ketinggian $146 \mathrm{~m}$ dpl dan Laboratorium Ilmu Tanah Universitas Lampung dari bulan Mei 2014 sampai September 2014. Alat-alat yang digunakan cangkul, meteran, alat tulis, neraca digital, oven, cutter, sprayer,ember, ayakan serta alat-alat lain untuk analisis tanah dan tanaman. Bahan-bahan yang digunakan dalam penelitian ini adalah benih jagung hibrida Bisi-18, pupuk urea , SP-36, $\mathrm{KCl}$, kompos, herbisida berbahan aktif isopropilamina glifosat dan isopropilamina 2,4-D serta bahan-bahan lain untuk analisis laboratorium tanah dan tanaman.

Percobaan dilakukan dengan Rancangan Acak Kelompok. Percobaan tersebut terdiri dari 4 perlakuan yaitu : olah tanah minimum (A), olah tanah minimum ditambahkan herbisida (B), olah tanah sempurna (C), olah tanah sempurna ditambahkan herbisda (D). Masingmasing perlakuan dilakukan sebanyak 4 ulangan. Homogenitas ragam diuji dengan uji Bartlet, aditivitas data diuji dengan uji Tukey. Jika asumsi terpenuhi data dianalisis dengan sidik ragam, perbedaan nilai tengah perlakuan diuji dengan uji Beda Nyata Terkecil (BNT) pada taraf $5 \%$.

Penanaman dilakukan dengan cara ditugal sedalam 3-5 $\mathrm{cm}$ dan ditanam 2 benih per lubang tanam dan dilakukan penjarangan sehingga tersisa satu tanaman yang tumbuh sehat. Aplikasi herbisida dilakukan pada saat sebelum penanaman dan pada saat tanaman berumur $6-8$ minggu setelah tanam dengan dosis 1,5 liter ha ${ }^{-1}$ dan volume semprot $160 \mathrm{cc}$. Pemberian pupuk kompos dengan dosis 10 ton ha ${ }^{-1}$ dilakukan 7 hari sebelum tanam dengan cara ditebarkan membentuk garis yang disesuaikan pada baris lobang tanam. Kemudian pemberian pupuk anorganik dengan dosis Urea $300 \mathrm{~kg}$ ha $^{-1}$, SP36 $100 \mathrm{~kg} \mathrm{ha}^{-1}$ dan KCL $200 \mathrm{~kg} \mathrm{ha}^{-1}$. Untuk pemberian urea dilakukan dua kali, yaitu $1 / 2$ dosis pada saat 3 Minggu Setelah Tanam (MST) dan $1 / 2$ dosis pada 7 MST. Sedangkan SP36 dan KCL diberikan hanya pada saat 3 MST. Panen dilakukan apabila telah menunjukkan ciri matang panen.

Pengambilan Sampel tanah diambil secara komposit, sebanyak 2 kali pada saat sebelum dan sesudah penanaman. Variabel yang diamati pada penelitian ini meliputi Variabel pengamatan yang diamati pada penelitian ini meliputi tinggi tanaman, jumlah daun, bobot kering pipilan, bobot kering berangkasan, bobot seratus butir, kadar air biji $14 \%$, bobot tongkol, analisis tanah, analisis tanaman, uji ekonomis.

Analisis tanah dilakukan setelah panen dengan cara pengambilan sampel tanah untuk dianalisisN-total, P-tersedia, K-dd, $\mathrm{pH}$ tanah, dan C-organik. Analisis tanaman dilakukan setelah panen dengan cara menganalisis kandungan $\mathrm{N}, \mathrm{P}$ dan $\mathrm{K}$ sampel tanaman

Uji korelasi dilakukan untuk melihat hubungan antara serapan $\mathrm{N}, \mathrm{P}$ dan $\mathrm{K}$ dengan pertumbuhan dan produksi tanaman jagung. Uji korelasi yang dilakukan ialah serapan NPK terhadap tinggi tanaman 7 MST, 
jumlah daun $8 \mathrm{MST}$, bobot basah pipilan, dan bobot basah brangkasan.

Uji ekonomis sistem olah tanah dilakukan dengan perhitungan indeks rasio penerimaan dan pengeluaran biaya. Soekartawi (1995) menyatakan bahwa $\mathrm{RC}^{-1}$ adalah perbandingan antara penerimaan total dengan biaya usaha tani (benih/bibit, pupuk, pestisida/herbisida, tenaga kerja, pengolahan tanah, pemeliharaan dan panen).

$$
\mathrm{R}=\frac{\mathrm{P} \times \mathrm{Q}}{\mathrm{C} 1+\mathrm{C} 2}
$$

Keterangan :

$\mathrm{R}=$ Nisbah penerimaan terhadap pengeluaran

$\mathrm{P}=$ Harga produksi jagung $(\mathrm{Rp} / \mathrm{kg})$

$\mathrm{Q}=$ Jumlah produksi jagung $(\mathrm{Kg} / \mathrm{ha})$

$\mathrm{C} 1=$ Upah pekerja $(\mathrm{Rp} / \mathrm{hari})$

$\mathrm{C} 2=$ Biaya herbisida $(\mathrm{Rp} / \mathrm{ha})$

Namun biaya penelitian ini C (cost) biaya untuk pengolahan tanah yang dihitung, sedangkan biaya lainnya diasumsikan sama untuk seluruh perlakuan. Apabila nilai ratio berdasarkan perhitungan tersebut $>1$ maka pengolahan tanah yang diuji memiliki nilai ekonomis yang lebih baik atau nilai $\mathrm{R}$ yang lebih tinggi menunjukkan nilai ekonomis yang lebih baik.

\section{HASIL DAN PEMBAHASAN}

Sifat Kimia. Berdasarkan hasil analisis tanah awal dan akhir (Tabel 1) menunjukan bahwa aplikasi sistem olah tanah dan herbisida meningkatkan $\mathrm{pH}$ dan P-tersedia tanah. Namun N-total dan C-organik tanah tetap pada kriteria mutu rendah, sedamgkan K-dd mengalami penurunan dari kriteria mutu tinggi menjadi rendah.

Peningkatan $\mathrm{pH}$ tanah dapat disebabkan pemberian pupuk kompos dengan dosis 10 ton $\mathrm{ha}^{-1}$ pada setiap petak percobaan mempengaruhi tingkat kemasaman tanah, dari kriteria agak masam (AM) menjadi netral (N). Sedangkan peningkatan P-tersedia diduga karena olah tanah sempurna dapat meningkatkan suhu tanah sehingga memacu mineralisasi $\mathrm{P}$ tidak tersedia menjadi $\mathrm{P}$ tersedia dan olah tanah sempurna menyebabkan unsur hara $\mathrm{P}$ lebih sulit tererosi (Adrinal dkk. (2012) dan Wardoyo (2008). Untuk kandungan K-dd tanah terjadi penurunan yang disebabkan tingginya unsur $\mathrm{K}$ yang diserap oleh tanaman, tingginya erosi, dan pencucian hara sehingga unsur K dalam tanah menurun. Selain itu menurut Razali (2002) unsur K didalam tanah dapat menurun karena $\mathrm{K}$ mempunyai tingkat kelarutan yang tinggi.

Tinggi Tanaman dan Jumlah Daun. Hasil analisis ragam menunjukkan bahwa tinggi tanaman dan jumlah daun tidak berbeda antar perlakuan setelah dilakukan percobaan; artinya sistem olah tanah dan aplikasi herbisida tidak berpengaruh terhadap tinggi tanaman jagung pada 7 minggu setelah tanam (MST) dan jumlah daun (Gambar 1 dan 2).

Aplikasi sistem olah tanah dan pemberian herbisida memang tidak berpengaruh nyata terhadap tinggi tanaman jagung pada $7 \mathrm{MST}$, namun tinggi tanaman pada percobaan ini sudah sesuai dengan kriteria tinggi tanaman jagung varietas BISI-18 yaitu $\pm 230 \mathrm{~cm}$ (Badan Penelitian Tanaman Serealia, 2010). Tinggi tanaman tertinggi terdapat pada perlakuan Olah tanah sempurna sebesar $247,06 \mathrm{~cm}$.

Pipilan Jagung. Hasil uji BNT menunjukkan bahwa bobot pipilan tertinggi terdapat pada perlakuan olah tanah minimum + herbisida dengan rerata masingmasing sebesar 14,$14 ; 10,59$ dan 9,23 $\mathrm{t} \mathrm{ha}^{-1}$ (Tabel 2).Tingginya produksi pipilan tanaman jagung pada perlakuan Olah tanah minimum + herbisidadibandingkan olah tanah sempurna dapat disebabkan beberapa faktor diantaranya meningkatnya ketersedian air tanah dan

Tabel 1. Hasil analisis kimia tanah awal dan tanah akhir setelah aplikasi olah tanah dan herbisida.

\begin{tabular}{lccccc}
\hline \multirow{2}{*}{ Jenis Analisis } & \multirow{2}{*}{ Tanah Awal } & \multicolumn{4}{c}{ Tanah Akhir Pelakuan } \\
\cline { 3 - 6 } & & $\mathrm{A}$ & $\mathrm{B}$ & $\mathrm{C}$ & $\mathrm{D}$ \\
\hline $\mathrm{pH}\left(\mathrm{H}_{2} \mathrm{O}\right)$ & $5,65(\mathrm{AM})^{*}$ & $6,62(\mathrm{~N})$ & $6,63(\mathrm{~N})$ & $7,37(\mathrm{~N})$ & $7,35(\mathrm{~N})$ \\
$\mathrm{N}$-total $(\%)$ & $0,16(\mathrm{R})$ & $0,17(\mathrm{R})$ & $0,17(\mathrm{R})$ & $0,17(\mathrm{R})$ & $0,16(\mathrm{R})$ \\
P-tersedia $(\mathrm{ppm})$ & $8,85(\mathrm{~S})$ & $10,49(\mathrm{~S})$ & $7,47(\mathrm{~S})$ & $24,28(\mathrm{ST})$ & $17,82(\mathrm{ST})$ \\
$\mathrm{K}_{\text {-dd }\left(\mathrm{Cmol}_{\mathrm{c}} \mathrm{kg}^{-1}\right)}$ & $0,80(\mathrm{~T})$ & $0,38(\mathrm{R})$ & $0,37(\mathrm{R})$ & $0,38(\mathrm{R})$ & $0,33(\mathrm{R})$ \\
C-Organik $(\%)$ & $1,48(\mathrm{R})$ & $1,59(\mathrm{R})$ & $1,6(\mathrm{R})$ & $1,77(\mathrm{R})$ & $1,81(\mathrm{R})$ \\
\hline
\end{tabular}

Keterangan: A (olah tanah minimum), B (olah tanah minimum + herbisida), C (olah tanah sempurna), D (olah tanah sempurna + herbisida), AM (Agak masam), N (Netral), R (Rendah), S (Sedang), T (Tinggi), ST (Sangat tinggi) ${ }^{*}$ Kriteria berdasarkan Balai Penelitian Tanah, 2005). 


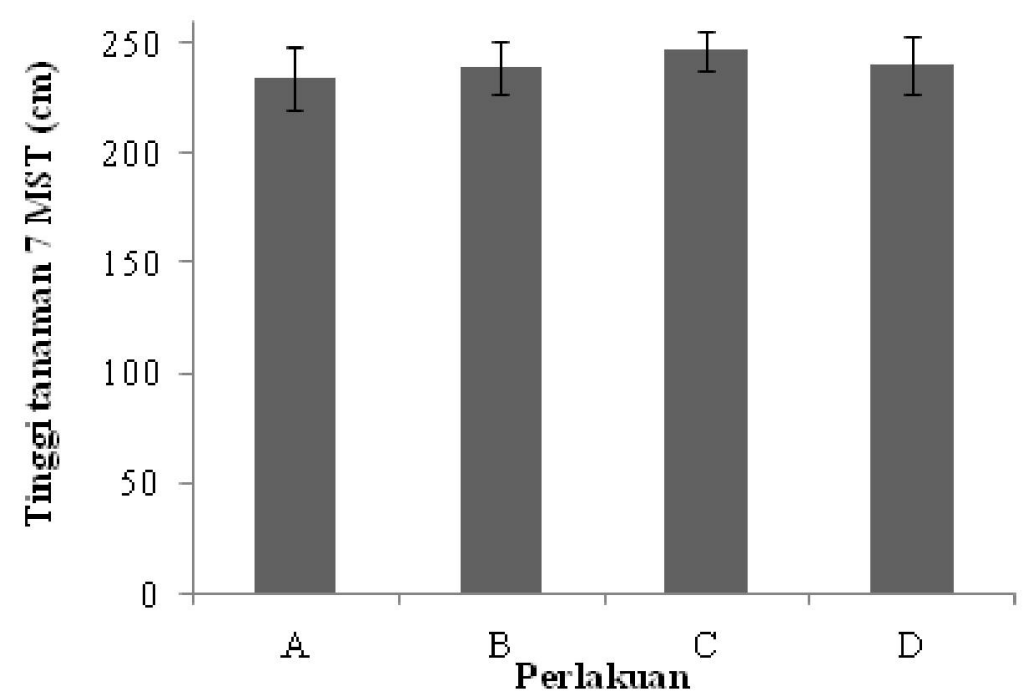

Gambar 1. Pengaruh sistem olah tanah dan herbisida terhadap tinggi tanaman jagung pada 7 MST $(\mathrm{cm})$. A (olah tanah minimum), B (olah tanah minimum + herbisida), C (olah tanah sempurna), D (olah tanah sempurna+herbisida). Tongkat pada bar menunjukkan standar deviasi.

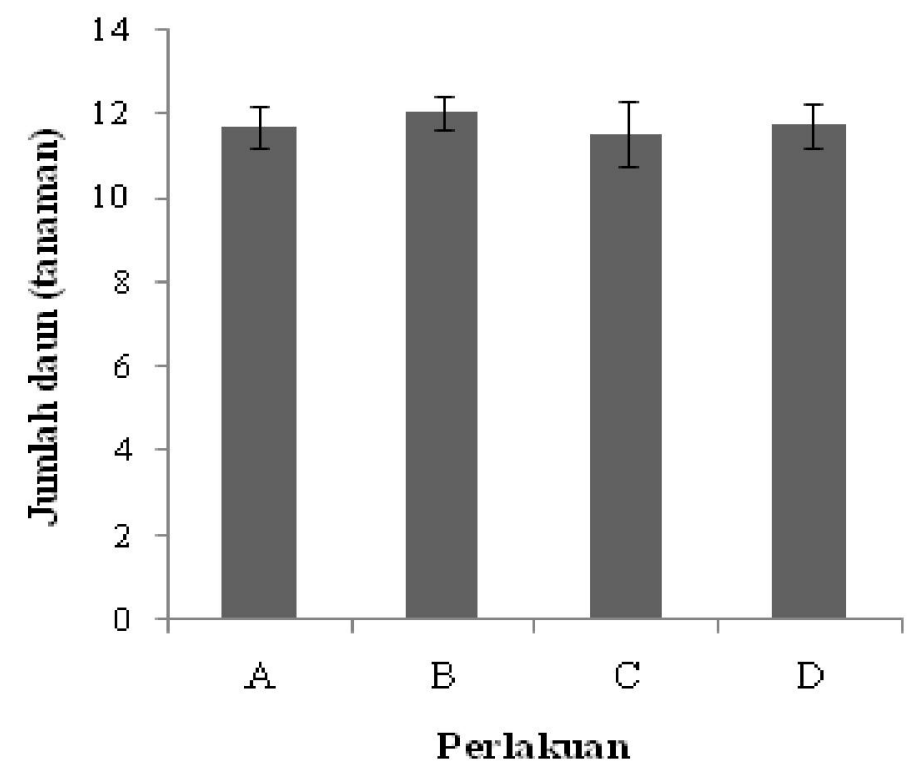

Gambar 2. Pengaruh sistem olah tanah dan herbisida terhadap jumlah daun tanaman jagung pada 7 MST (cm). A (olah tanah minimum), B (olah tanah minimum + herbisida), C (olah tanah sempurna), D (olah tanah sempurna + herbisida). Tongkat pada bar menunjukkan standar deviasi.

Tabel 2. Pengaruh sistem olah tanah dan herbisida terhadap bobot pipilan tanaman jagung.

\begin{tabular}{lccc}
\hline & \multicolumn{3}{c}{ Bobot pipilan jagung $\left(\mathrm{t} \mathrm{ha}^{-1}\right)$} \\
\cline { 2 - 4 } Perlakuan & $\begin{array}{c}\text { Bobot pipilan } \\
\text { basah }\end{array}$ & $\begin{array}{c}\text { Bobot pipilan } \\
\text { kering oven }\end{array}$ & $\begin{array}{c}\text { Bobot pipilan } \\
\text { KA 14\% }\end{array}$ \\
\hline Olah tanah minimum & $11,56 \mathrm{a}$ & $8,66 \mathrm{ab}$ & $7,54 \mathrm{~b}$ \\
Olah tanah minimum +herbisida & $14,14 \mathrm{~b}$ & $10,59 \mathrm{c}$ & $9,23 \mathrm{c}$ \\
Olah tanah sempurna & $11,14 \mathrm{a}$ & $7,8 \mathrm{a}$ & $6,37 \mathrm{a}$ \\
Olah tanah sempurna + herbisida & $12,51 \mathrm{~b}$ & $9,15 \mathrm{~b}$ & $7,77 \mathrm{~b}$ \\
\hline BNT 5\% & 1,62 & 1,07 & 0,99 \\
\hline
\end{tabular}

Keterangan: Kolom yang diikuti oleh huruf yang sama tidak berbeda nyata pada uji BNT taraf $5 \%$. 
dekomposisi serasah gulma menjadi bahan organik tanah yang dapat dimanfaatkan tanaman dalam proses pengisian biji. Dikemukakan Albayadi (2005) bahwa pengolahan tanah yang dilakukan secara sempurna atau intensif akan mempercepat laju infiltrasi dan aliran permukaan sehingga meningkatkan erosi.

Brangkasan Tanaman. Hasil analisis ragam menunjukkan bahwa pengaruh sistem olah tanah dan herbisida tidak berbeda nyata terhadap bobot total brangkasan basah dan kering. Bobot brangkasan totalbasah dan kering tertinggi terdapat pada perlakuan Olah tanah minimum + herbisida sebesar 31,$56 ; 8,79 \mathrm{t}$ ha $^{-1}$ (Gambar 3). Hal ini dapat disebabkan pertumbuhan vegetatif tanaman jagung menghasilkan biomasa yang bobotnya tidak jauh berbeda antar perlakuan. Menurut Dwidjoseputro (1994) pertumbuhan tanaman ditunjukkan oleh bertambahnya ukuran dan berat kering brangkasan yang dicerminkan dengan bertambahnya protoplasma yang terjadi karena bertambahnya ukuran sel.
Bobot 100 butir. Hasil uji BNT pada Tabel 3, perlakuan olah tanah sempurna + herbisida menunjukkan hasil bobot 100 butir tertinggi $\left(36,12 \mathrm{~g}(100 \mathrm{butir})^{-1}\right)$. Pada penelitian ini untuk bobot 100 butir kadar air biji jagung $14 \%$ tidak diukur. Tingginya bobot 100 butir olah tanah sempurna + herbisida disebabkan ukuran biji jagung lebih besar dibandingkan perlakuan lainnya.

Bobot Kering Total Jagung. Hasil uji BNT pada Tabel 4 menunjukan perlakuan olah tanah minimum + herbisida menghasilkan bobot tertinggi sebesar 19,38 ton ha ${ }^{-1}$ dibandingkan perlakuan lainnya. Hal ini disebabkan perlakuan olah tanah minimum + herbisida menghasilkan serasah gulma yang dapat meningkatkan kelembaban tanah dan ketersedian air tanah. Syaputra (2012) menjelaskan peningkatan produksi tanaman pada olah tanah minimun dibandingkan olah tanah intensif disebabkan oleh beberapa faktor diantaranya meningkatnya ketersediaan air tanah. Menurut Rachman dkk. (2004) Pada perlakuan olah tanah

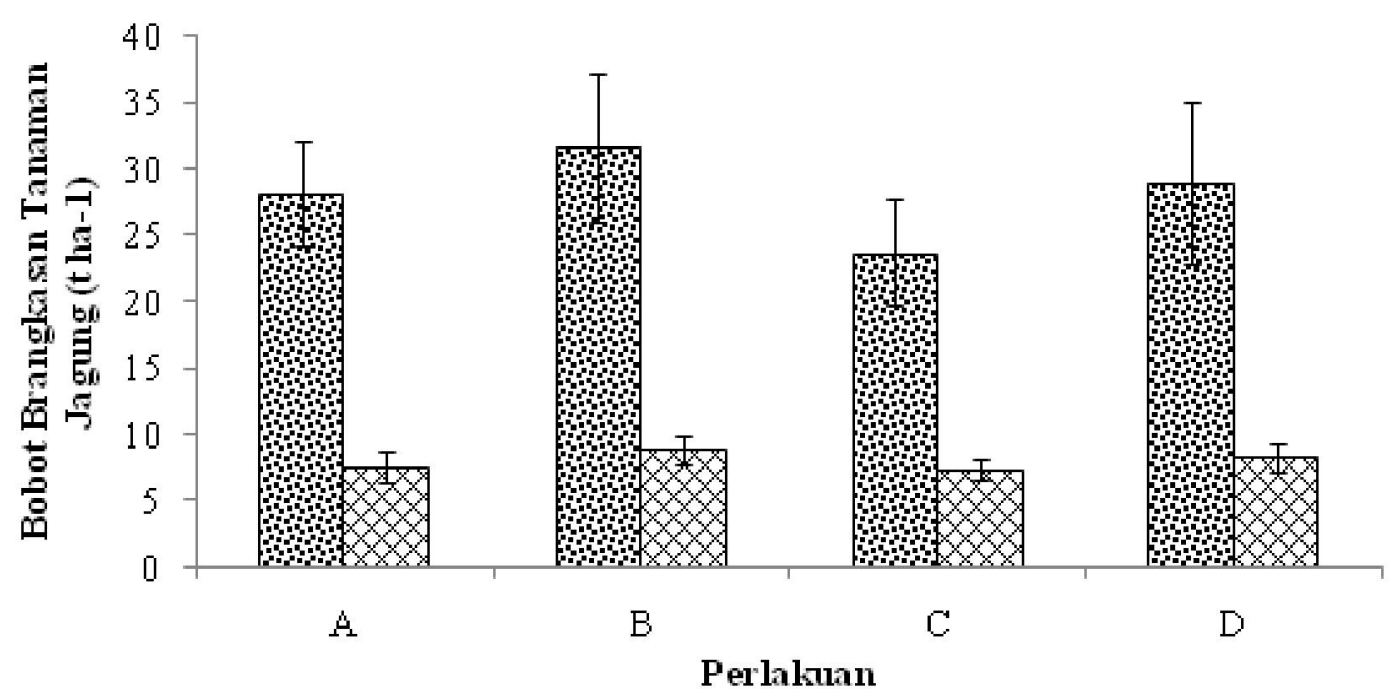

Gambar 3. Pengaruh sistem olah tanah dan herbisida terhadap bobot brangkasan total tanaman jagung $\left(\mathrm{t}\right.$ ha $\left.{ }^{1}\right)$. A (olah tanah minimum), B (olah tanah minimum + herbisida), C (olah tanah sempurna), D (olah tanah sempurna + herbisida). Tongkat pada bar menunjukkan standar deviasi. $\mathbf{A}$ 'BB = berat basah; $\mathrm{BK}$ $=$ berat kering.

Tabel 3. Pengaruh sistem olah tanah dan herbisida terhadap bobot 100 butir tanaman jagung.

\begin{tabular}{rc}
\hline Perlakuan & Bobot 100 butir (gram) \\
\hline Olah tanah minimum & $32,27 \mathrm{a}$ \\
Olah tanah minimum + herbisida & $32,07 \mathrm{a}$ \\
Olah tanah sempurna & $31,82 \mathrm{a}$ \\
Olah tanah sempurna + herbisida & $36,12 \mathrm{~b}$ \\
\hline BNT 5\% & 2,75 \\
\hline
\end{tabular}

Keterangan: Kolom yang diikuti oleh huruf yang sama tidak berbeda nyata pada uji BNT taraf 5\%. 
minimum dapat menurunkan evaporasi dan meningkatkan infiltrasi yang menyebabkan kandungan air tanah lebih tinggi disekitar daerah perakaran tanaman jagung dibandingkan olah tanah intensif. Sehingga hasil tanaman (bobot kering total seluruh tanaman) jagung akan lebih tinggi pada perlakuan olah tanah minimum + herbisida.

Jumlah Hara N Terangkut Panen. Hasil uji BNT pada Tabel 5 menunjukan bahwaaplikasi olah tanah dan herbisida berpengaruh nyata terhadap serapan hara $\mathrm{N}$ pipilan, bonggol, dan total tanaman jagung. Serapan $\mathrm{N}$ pipilan, bonggol, dan total tanaman jagung tertinggi terdapat pada perlakuan olah tanah minimum+herbisida, dengan nilai masing-masing 142,$11 ; 7,25$; dan 208,20 kg ha ${ }^{-1}$.

Sesuai dengan penelitian Golabi dkk. (2008) bahwa sistem OTS mengalamipenurunan laju infiltrasi sejak berhentihujan sampai dengan menit ke-60, karenastrukturnya terganggu dan porinya tidakmenyambung. Artinya aliran air yang membawa pupuk $\mathrm{N}$ juga terganggu penyerapannya. Peningkatan serapan $\mathrm{N}$ tanaman ada keterkaitannya dengan peningkatan bobot kering tanaman dan peningkatan ketersediaan $\mathrm{N}$ tanah. Hal tersebut akan menyebabkan peningkatan kemampuan akar tanaman untuk menyerap air dan unsur hara $\mathrm{N}$ dalam tanah yang akan menunjang peningkatan perkembangan tanaman karena $\mathrm{N}$ tidak menguap dan pori tanah tidak terbuka, (Mengel dkk., 2001).

Jumlah Hara P Terangkut Panen. Hasil uji BNT pada Tabel 6 menunjukan bahwaaplikasi olah tanah dan herbisida berpengaruh nyata terhadap serapan hara $\mathrm{P}$ pipilan dan total tanaman jagung. Kandungan hara Ppipilan dan totaltanaman tertinggi terdapat pada perlakuan olah tanah minimum + herbisida sebesar 46,14 dan $63,72 \mathrm{~kg} \mathrm{ha}^{-1}$, sedangkan kandungan hara $\mathrm{P}$ pipilan dan total tanaman terendah terdapat pada perlakuan olah tanah minimum sebesar 21,88 dan 37,08 $\mathrm{kg} \mathrm{ha}^{-1}$.

Hal ini disebabkan karena dari segi aliran serapan pupuk lewat pori kapiler tidak terganggu oleh struktur tanah yang tidak diolah, bagian yang diolah hanya pada tempat tumbuhnya benih saja. Artinya pertumbuhan

Tabel 4. Pengaruh sistem olah tanah dan herbisida terhadap bobot kering total tanaman jagung.

\begin{tabular}{lcccc}
\hline Perlakuan & $\begin{array}{c}\text { Berangkasan } \\
\text { tanpa } \\
\text { bonggol } \\
\left.\text { (ton ha }^{-1}\right)\end{array}$ & $\begin{array}{c}\text { Bonggol } \\
\left.\text { (ton ha }^{-1}\right)\end{array}$ & $\begin{array}{c}\text { Pipilan } \\
\left.\text { (ton ha }^{-1}\right)\end{array}$ & $\begin{array}{c}\text { Total } \\
\left.\text { (ton ha }^{-1}\right)\end{array}$ \\
\hline Olah tanah minimum & 6,27 & 1,22 & $8,66 \mathrm{ab}$ & $16,16 \mathrm{a}$ \\
Olah tanah minimum + herbisida & 7,45 & 1,34 & $10,59 \mathrm{c}$ & $19,38 \mathrm{~b}$ \\
Olah tanah sempurna & 6,19 & 1,11 & $7,80 \mathrm{a}$ & $15,10 \mathrm{a}$ \\
Olah tanah sempurna + herbisida & 6,95 & 1,25 & $9,14 \mathrm{~b}$ & $17,35 \mathrm{ab}$ \\
\hline BNT 5\% & tn & tn & 1,07 & 2,81 \\
\hline
\end{tabular}

Keterangan: Kolom yang diikuti oleh huruf yang sama tidak berbeda nyata pada uji BNT taraf 5\%.

Tabel 5. Pengaruh sistem olah tanah dan herbisida terhadap serapan hara $\mathrm{N}$ tanaman jagung.

\begin{tabular}{lcccc}
\hline & \multicolumn{4}{c}{ Serapan hara N tanaman jagung $\left(\mathrm{kg} \mathrm{ha}^{-1}\right)$} \\
\cline { 2 - 5 } Perlakuan & $\begin{array}{c}\text { Brangkasan } \\
\text { tanpa } \\
\text { bonggol }\end{array}$ & Bonggol & Pipilan & Total \\
\hline Olah tanah minimum & 48,31 & $4,90 \mathrm{a}$ & $105,63 \mathrm{~b}$ & $158,84 \mathrm{a}$ \\
Olah tanah minimum + herbisida & 58,48 & $7,25 \mathrm{~b}$ & $142,11 \mathrm{c}$ & $208,20 \mathrm{~b}$ \\
Olah tanah sempurna & 53,21 & $6,96 \mathrm{~b}$ & $87,92 \mathrm{a}$ & $148,09 \mathrm{a}$ \\
Olah tanah sempurna + herbisida & 61,90 & $5,00 \mathrm{a}$ & $94,10 \mathrm{ab}$ & $161,00 \mathrm{a}$ \\
\hline BNT 5\% & th & 1,16 & 13,89 & 25,97 \\
\hline
\end{tabular}

Keterangan: Kolom yang diikuti oleh huruf yang sama tidak berbeda nyata pada uji BNT taraf $5 \%$. 
benih bisa maksimum ditambah aliran air dari sekitar tanaman masih menyambung, Sedangkan pada sistem OTS semua struktur tanah disekitar tanaman terganggu karena diolah, sehingga aliran serapan pupuk agak terganggu (Wardoyo, 2008).

Serapan Hara K Terangkut Panen. Hasil uji BNT pada Tabel 7 menunjukan bahwa aplikasi olah tanah dan herbisida berpengaruh nyata terhadap serapan hara $\mathrm{K}$ pipilan dan total tanaman jagung. Kandungan hara $\mathrm{K}$ pipilan dan total tanaman jagung tertinggi terdapat pada perlakuan olah tanah minimum + herbisida sebesar 72,90 dan 204,06 $\mathrm{kg} \mathrm{ha}^{-1}$, sedangkan kandungan hara K pipilan dan total tanaman terendah terdapat pada perlakuan olah tanah minimum sebesar 27,91 dan 140,17 $\mathrm{kg} \mathrm{ha}^{-1}$ (Tabel 7).

Olah tanah minimum + herbisida menghasilkan serasah gulma yang dapat meningkatkan kelembaban tanah dan ketersedian air tanah serta tidak terjadi persaingan dengan gulma dalam penyerapan unsur hara K. Menurut Olson dan Sander (1988) beberapa faktor yang mempengaruhi ketersedian hara dalam tanah untuk dapat diserap tanaman adalah total pasokan hara, kelembaban dan aerasi tanah, suhu tanah, serta sifat fisik maupun kima tanah.

Uji Korelasi. Berdasarkan uji korelasi yang telah dilakukan serapan hara N, P dan K berkorelasi terhadap jumlah daun, bobot pipilan, bobot bonggol dan bobot brangkasan total namun tidak berkorelasi terhadap tinggi tanaman jagung. Hal tersebut tercermin pada nilai koefisien korelasi (r) yang memiliki nilai mendekati 1 (Tabel 8). Semakin tinggi serapan unsur hara N, P dan $\mathrm{K}$ maka semakin tinggi produksi jagung dan bobot berangkasan tanaman. Hubungan antara kadar nitrogen dan kalium berbanding positif dengan berat kering brangkasan yang dihasilkan. Hal tersebut menunjukkan bahwa kadar nitrogen dan kalium dalam tanaman berhubungan erat dengan berat kering tanaman yang dihasilkan (Yudono, 2000).Namun serapan hara tidak berkorelasi tehadap tinggi tanaman jagung. Hal ini disebabkan karena pertumbuhan jagung mempunyai batas maksimal yaitu saat malai mulai muncul sehingga serapan unsur hara tidak mempengaruhi tinggi tanaman.

Tabel 6. Pengaruh sistem olah tanah dan herbisida terhadap serapan hara P tanaman jagung.

\begin{tabular}{lcccc}
\hline & \multicolumn{4}{c}{ Serapan hara P tanaman jagung $\left(\mathrm{kg} \mathrm{ha}^{-1}\right)$} \\
\cline { 2 - 5 } Perlakuan & $\begin{array}{c}\text { Brangkasan } \\
\text { tanpa } \\
\text { bonggol }\end{array}$ & Bonggol & Pipilan & Total \\
\hline Olah tanah minimum & 13,80 & 2,20 & $21,88 \mathrm{a}$ & $37,08 \mathrm{a}$ \\
Ol ah tanah minimum + herbisi da & 14,90 & 2,68 & $46,14 \mathrm{~d}$ & $63,72 \mathrm{c}$ \\
Ol ah tanah sempurna & 13,61 & 2,65 & $31,85 \mathrm{~b}$ & $48,11 \mathrm{~b}$ \\
Olah tanah sempurna + herbisida & 15,30 & 2,25 & $38,88 \mathrm{c}$ & $56,43 \mathrm{c}$ \\
\hline BNT 5\% & tn & tn & 4,25 & 7,34 \\
\hline
\end{tabular}

Keterangan: Kolom yang diikuti oleh huruf yang sama tidak berbeda nyata pada uji BNT taraf $5 \%$.

Tabel 7. Pengaruh sistem olah tanah dan herbisida terhadap serapan hara $\mathrm{K}$ tanaman jagung.

\begin{tabular}{lcccc}
\hline & \multicolumn{3}{c}{ Serapan hara $\mathrm{K}$ tanaman jagung $\left(\mathrm{kg} \mathrm{ha}^{-1}\right)$} \\
\cline { 2 - 5 } Perlakuan & $\begin{array}{c}\text { Brangkasan } \\
\text { tanpa } \\
\text { bonggol }\end{array}$ & Bonggol & Pipilan & Total \\
\hline Olah tanah minimum & 104,78 & 7,5 & $27,91 \mathrm{a}$ & $140,17 \mathrm{a}$ \\
Olah tanah minimum + herbisida & 123,64 & 7,5 & $72,90 \mathrm{~d}$ & $204,06 \mathrm{c}$ \\
Olah tanah sempurna & 97,76 & 6,2 & $45,23 \mathrm{~b}$ & $149,19 \mathrm{ab}$ \\
Olah tanah sempurna + herbisida & 113,37 & 6,9 & $61,43 \mathrm{c}$ & $181,68 \mathrm{bc}$ \\
\hline BNT 5\% & tn & tn & 6,03 & 33,00 \\
\hline
\end{tabular}

Keterangan: Kolom yang diikuti oleh huruf yang sama tidak berbeda nyata pada uji BNT taraf $5 \%$. 
Uji Ekonomis. Berdasarkan hasil uji ekonomis yang telah dilakukan terhadap aplikasi olah tanah minimum + herbisida menghasilkan nilai rasio tertinggi dibandingkan perlakuan lainnya sebesar 2,50 (Tabel 9). Nilai rasio terendah terdapat pada perlakuan olah tanah sempurna sebesar 1,61. Dengan demikian apabila dilakukan usaha budidaya tanaman jagung, maka perlakuan olah tanah minimum + herbisida lebih menguntungkan secara ekonomi dibandingkan perlakuan lain.

Tabel 8. Uji korelasi antara serapan NPK dengan pertumbuhan dan produksi tanaman jagung.

\begin{tabular}{clcc}
\hline No & \multicolumn{1}{c}{ Uji Korelasi } & Persamaan & $\mathrm{R}$ \\
\hline 1 & Serapan N vs Tinggi & $\mathrm{y}=214,4+0,244 \mathrm{x}$ & $0,34 \mathrm{tn}$ \\
2 & Serapan P vs Tinggi & $\mathrm{y}=209,0+0,944 \mathrm{x}$ & $0,34 \mathrm{tn}$ \\
3 & Serapan K vs Tinggi & $\mathrm{y}=230,5+0,054 \mathrm{x}$ & $0,12 \mathrm{tn}$ \\
4 & Serapan N vs Jumlah daun & $\mathrm{y}=9,715+0,019 \mathrm{x}$ & $0,59^{*}$ \\
5 & Serapan P vs Jumlah daun & $\mathrm{y}=9,020+0,083 \mathrm{x}$ & $0,66^{*}$ \\
6 & Serapan K vs Jumlah daun & $\mathrm{y}=9,091+0,015 \mathrm{x}$ & $0,71^{*}$ \\
7 & Serapan N vs Bobot pipilan & $\mathrm{y}=7,058+0,049 \mathrm{x}$ & $0,77^{*}$ \\
8 & Serapan P vs Bobot pipilan & $\mathrm{y}=8,513+0,110 \mathrm{x}$ & $0,72^{*}$ \\
9 & Serapan K vs Bobot pipilan & $\mathrm{y}=9,290+0,058 \mathrm{x}$ & $0,72^{*}$ \\
10 & Serapan N vs Bobot bonggol & $\mathrm{y}=0,415+0,016 \mathrm{x}$ & $0,67^{*}$ \\
11 & Serapan P vs Bobot bonggol & $\mathrm{y}=0,029+0,066 \mathrm{x}$ & $0,70^{*}$ \\
12 & Serapan K vs Bobot bonggol & $\mathrm{y}=0,648+0,008 \mathrm{x}$ & $0,54^{*}$ \\
19 & Serapan N vs Bobot brangkasan total & $\mathrm{y}=6,391+0,207 \mathrm{x}$ & $0,63^{*}$ \\
20 & Serapan P vs Bobot brangkasan total & $\mathrm{y}=1,564+0,901 \mathrm{x}$ & $0,72^{*}$ \\
21 & Serapan K vs Bobot brangkasan total & $\mathrm{y}=5,810+0,193 \mathrm{x}$ & $0,91^{*}$ \\
\hline
\end{tabular}

Keterangan : $r$ : koefisien korelasi linier, * : berbeda nyata taraf $5 \%$, th : tidak berbeda nyata taraf $5 \%$.

Tabel 9. Indeks uji ekonomis aplikasi sistem olah tanah dan herbisida terhadap tanaman jagung.

\begin{tabular}{lc}
\hline \multicolumn{1}{c}{ Perlakuan } & Rasio \\
\hline Olah tanah minimum & 2,14 \\
Olah tanah minimum +herbisida & 2,50 \\
Olah tanah sempurna & 1,61 \\
Olah tanah sempurna + herbisida & 1,89 \\
\hline
\end{tabular}

Keterangan: Bila rasio $>1$ maka sistem olah tanah yang diuji memiliki nilai ekonomis yang baik

\section{KESIMPULAN}

Kesimpulan yang didapat dari penelitian ini: (1) Olah tanah minimum + herbisida secara nyata menghasilkan bobot pipilan basah, bobot pipilan kering oven, bobot pipilan KA $14 \%$, dan bobot kering total tanaman tertinggi dibandingkan olah tanah minimum, olah tanah sempurna, dan olah tanah sempurna + herbisida; (2) Olah tanah minimum + herbisida secara nyata menghasilkan serapan hara total tanaman N, P, dan $\mathrm{K}$ tertinggi dibandingkan olah tanah minimum, olah tanah sempurna, dan olah tanah sempurna + herbisida; (3) Serapan hara N P K berkorelasi positif terhadap jumlah daun, bobot pipilan, bobot bonggol, dan bobot brangkasan tanaman jagung; (4) Olah tanah minimum + herbisida menghasilkan nilai ekonomis tertinggi dibandingkan olah tanah minimum, olah tanah sempurna, dan olah tanah sempurna + herbisida.

\section{DAFTAR PUSTAKA}

Adrinal, A.S. dan Gusmini. 2012. Perbaikan sifat fisika kimia tanah psamment dengan pemulsaan organik dan olah tanah konservasi pada budidaya jagung. Jurnal Solum 9 (1) : 25-35. 
Albayadi. 2005. kajian sistem olah tanah dan pemberian mulsa jerami padi terhadap erosi tanah ultisol serta hasil jagung. Proseding Seminar Nasional Hasil-hasil Penelitian. Jambi 23-25 November 2005. $279-284$.

Azwir. 2012. Pengaruh sistem persiapan lahan terhadap pertumbuhan dan hasil jagung hibrida. Jurnal Balai Pengkajian Teknologi Pertanian. 38-46.

Balai Penelitian Tanaman Serealia. 2010. Deskripsi Varietas Jagung Unggul. Balai Penelitian Tanaman Serealia. Maros. Sulawesi Selatan. 92 hlm.

BPS. 2014. Data Produktivitas Jagung Indonesia pada tahun 2013 (http;//www.bps.go.id). Diakses pada 2 Juni 2014.

Dwidjoseputro. 1994. Pengetahuan Fisiologi Tumbuhan. Gramedia. Jakarta. 232 hlm.

Golabi, M. H., S. A. El-Swaify, and C. Iyekar. 2014. Experiment ofNo-Till Farming System on the Volcanic Soils of Tropical Islands of Micronesia. International Soil and Water Conservation Research. P. 30 - 39.

Mengel, K., E. A. Kirkby, H. Kosegarten and T. Appel. 2001. Principles of Plant Nutrition. $5^{\text {th }}$ Ed., Kluwer Academic Publ., London. 849 hlm.

Olson, R.A. and D. H. Sandor. 1988. Corn Production. In Monograph : Agronomy Corn Improvement. Wisconsin. P . $639-686$.
Rachman, A., A. Dariah, dan E. Husen. 2004. Konservasi Tanah Pada Lahan Kering Belerang. Pusat Penelitian dan Pengembangan Tanah dan Agroklimat. Badan Litbang Pertanian. $204 \mathrm{hlm}$.

Razali. 2002. Pengomposan dan Pengaruh Pemberian Kompos Pupuk Biologi serta Amandemen terhadap Pertumbuhan, Ketersediaan, serta Serapan HaraTanaman Kedelai pada Tanah Ultisol Langkat. Tesis. Fakultas Pertanian. Universitas Sumatera Utara. $82 \mathrm{hlm}$.

Soekartawi. 1995. Teori Ekonomi Produksi. Rajawali Pers. Jakarta. $257 \mathrm{hlm}$.

Syaputra, A. 2012. Pengaruh Sistem Olah Tanah dan Pemupukan Nitrogen Jangka Panjang terhadap Laju Dekomposisi Mulsa In Situ dan Produksi Tanaman Jagung (Zea Mays L.) di Tanah Ultisol. Skripsi. Universitas Lampung. Lampung. $61 \mathrm{hlm}$.

Utomo, M. 1995. Kekerasan tanah dan serapan hara tanaman jagung pada olah tanah konservasi jangka panjang. J. Tanah Trop. 1: 1-7.

Wardoyo, S. 2008. Aplikasi olah tanah konservasi dan pupuk $n$ pada entisol serta pengaruhnya terhadap serapan npk tanaman jagung. Jurnal Agrin. 12 (2): 227-236.

Yudono, A. D. 2000. Pengaruh Pengembalian Biomassa Bangkuang terhadap Sifat Tanah dan Pertumbuhan Jagung. Skripsi. Institut Pertanian Bogor. Bogor. 54 hlm. 